\title{
The impact of ownership structure on corporate performance (business-operating result) of listed companies on Ho Chi Minh Stock Exchange - A comparison the period 2006-2008 vs 2015-2017 - 10 years overview
}

\author{
Do Thi Thanh Tram ${ }^{1 *}$, Nguyen Thi Minh Hue ${ }^{2}$ \\ ${ }^{1}$ Intradin VietNam Co., Ltd., Vietnam \\ ${ }^{2}$ Freelancer, Vietnam \\ *Corresponding author: dothithanhtram2321@gmail.com
}

\begin{tabular}{ll}
\hline ARTICLE INFO & ABSTRACT \\
\hline
\end{tabular}

DOI: $10.46223 / \mathrm{HCMCOUJS}$. econ.en.10.2.968.2020

Received: September $26^{\text {th }}, 2019$

Revised: December $7^{\text {th }}, 2019$

Accepted: July $13^{\text {th }}, 2020$

Keywords:

ROA, ROE, P, P/B, A12
This research studies the relationship between equity structure and business performance/ operating results of listed companies on HOSE for three years 2015, 2016, and 2017. This is not only an important aspect of corporate governance but also more important for companies operating in the form of a jointstock company. The author uses the Enterprise Management System theory and references $\mathrm{Xu}$ and Wang's research model applied to Chinese joint-stock companies (1997). The used data is secondary data including indicators showing the company's business results (ROA, ROE, P/B) and equity ratios of shareholders (ownership concentration, ownership components). The research method was performed by regression analysis using SPSS software, in which the dependent variables are indicators of the company's business results, the main independent variables represent the equity structure. After analyzing data, the study has drawn two main results. The first result is that the ownership component of individuals (personal) hurts on the business performance of companies, in contrast to the fraction of equity owned by state and equity owned by legal person/institution (organizational entities) do not have any influence on the linear correlation. The second result is the concentration of ownership has no relation to the business performance of companies. With the above results, this topic can be studied more extensively for all types of other ownership such as domestic shareholders and foreign shareholders; due to both two types increasingly essential for companies and investors in the joint-stock market.

\section{Introduction}

In 2006, Vietnam joined the WTO, the economy in general, and the financial sector have been gradually integrated into the world economy. Vietnam's economic structure is increasingly diversified with different types of ownership and different types of businesses. The goal is to build the economy into a socialist - modernized, industrialized country, in which the key economic sectors and sectors are controlled by the state at many levels. Most of the equitized enterprises are still managed and controlled by the state due to its high proportion of capital. 
Also since 2006 until now, Vietnam's financial market has developed with rapid growth. The stock market is a platform for mobilizing investment capital for the economy, providing an investment environment for the public, and creating an environment for the government to implement macro policies. With the gains from the stock market, equitization is now a common trend for business development in Vietnam market.

Therefore, the goal of the current government is to promote the equitization of stateowned enterprises. However, the equitization of state-owned enterprises is still in the initial stage of implementation and many issues need to be corrected. Looking back, the Vietnam stock market was born in 2000 and developed through different periods. In 2008, the world economic crisis affected the economy of Vietnam and the Vietnam stock market saw a severe decline. Fortunately, the stock market has recovered and attracted more investors with a trading volume reaching a record level so far.

Over 20 years, Vietnam's stock market has experienced a lot of changes, but it is also growing more and more strongly, through many different periods. The period 2000-2005 marked the beginning of the stock market, or it was considered a toddler period. During this period, market capitalization reached just under $1 \%$ of GDP and contributed insignificantly to the economy. However, in the period from 2006, when the Law on Securities was enacted and officially took effect from the beginning of 2007, it gradually improved its inadequacies and, conflicts with other legal documents helped the stock market. For instance, Vietnam stock market can integrate more with international and regional capital markets. Also, the second half of 2017 marked the market of derivative securities in Vietnam (August 10, 2017), becoming a new profitable investment channel for individual investors Vietnam stock market becomes safe and more transparent, increased management capabilities for state management agencies.

\section{Literature review and methodology}

\subsection{Focus on ownership and owned components}

In the enterprise probation system, a factor that greatly influences the rights of business management and that is the structure of equity. There are many studies on this issue and the results show that the structure of equity has an impact on the business performance of the business. And the level of influence as well as which components affect the business is done by economic researchers doing many statistical studies at businesses across the country. In this article, the main research objective is to find out the relationship between equity structure owning business results of companies listed on HOSE. Is the business affected by ownership concentration? Which ownership component affects the business the most? Those are the problems that this paper needs to find out.

\subsubsection{Focus on ownership of corporate performance results}

There are two issues of debate about the role of centralized ownership or major shareholders in the system business management system. According to financial theory, it is often assumed that businesses owned by many different small shareholders (also called dispersal of ownership) are more efficient than the high-concentration enterprises-listed company (Fama \& Jensen, 1985). Specifically, these shareholders use the basic rules of the market to assess their investment and, in addition, a dynamic market for enterprise management will automatically promote the motivation to reduce the severity of abuse of management rights. The level of ownership is dispersed so the power is not on one side but spreads out many people. This helps the company not be too dependent on a certain shareholder. However, other studies suggested 
that the concentration of ownership will increase the performance of the enterprise by the major shareholders will ensure the level of benefits between managers and owners of the company (Anderson, Mansi, \& Reeb, 2003), improving supervision as well as investment decisions. Although major shareholders offer potential profits, power and their influence also indicate that they can deprive business resources karma to serve their interests without regard to the interests of other shareholders (Faccio, Lang, \& Young, 2001). Also, Demsetz and Lehn (1985) studied and found that there is no influential relationship between ownership concentration and ROE. Some previous studies in the U.S. affirmed that concentration of ownership has a positive relationship to business value (Tobin's Q) at low ownership.

H1: Concentration of ownership has a positive effect on the business performance of enterprises. (corporate performance-operating result)

\subsubsection{Ownership components and ownership roles for business performance/operating result}

In the equity structure of joint-stock companies, the list of shareholders is clearly distinguished from the ownership components. There are three main ownership components: government, organization, and individual. Due to the political characteristics in Vietnam, usually, businesses in the business sector are important to the national economy (such as electricity and food), the government owns a large portion of capital, accounting for a high proportion. However, follow the general trend of economic development, the Vietnamese government has transformed the Vietnamese economy to develop according to the market economy trend since the 1980s. Continuing with the world, the state has also started to equitize enterprises to the government since 2000. As a result, this trend is being promoted more strongly than ever. This has helped existing businesses have more ownership components.

Government/State shareholders: State shareholders are equity which is invested by government capital center, local government, or state-owned enterprises. State shares are not allowed to trade more than twice but are transferable to domestic organizations. In many businesses that are widely traded, the state is the largest shareholder or major shareholder. In state-owned listed joint-stock companies, officials of the local finance department as representatives of the state will exercise the rights of the owner. On the one hand, it is very difficult for the state to distinguish clearly the decisions of the board of directors, which decision increases the value of state assets, the decision which reduces the value of state assets. State representatives are sometimes not industrial experts, the value of state assets is not easy to determine. Because stock prices are volatile and include many factors affecting it, it is considered unfair and inaccurate to value state assets based on stock prices. Responding to this view, the actual value of state assets is valued by the book value of net assets under state ownership. However, the book value is not related to the profit portion of the company and therefore is not related to the present value of the company. Therefore, ambiguity in management is inevitable. Another ineffective element of state administration is the increase in the conflict of interest between the state government and other shareholders. For example, when a company wants to increase its charter capital through voting rights at the general meeting of shareholders, the state capital representatives in the board will vote against this because of concerns that the capital increase will reduce the state ownership rate. Moreover, it can be caused that reducing benefits in managing and making decisions in the business. For these reasons, state equity is a matter of concern for investors, who consider it to harm the business performance/operating results. However, in the economic and political context of Vietnam, will the companies with large state capital be negatively affected as other countries have studied? It is the above things that make the second assumption/hypothesis: 
H2: State/Governmental equity has a negative impact on performance business performance/operating results

Shareholders of legal entities/individual: Shareholders of legal entities/ individuals are the equity part of organizations with legal status, including private companies, financial institutions such as securities companies, banks, mutual funds, financial lenders, and other types of businesses. The legal shareholder is the second largest group of shareholders in the list of shareholders of joint-stock companies. The important goal of this ownership is that they invest in economic direction and seek profit. Legal shareholders do not necessarily need to pay attention to the goals considered important for state shareholders. In the previous study of $\mathrm{Xu}$ and Wang (1997), they found that the level of ownership concentration of high legal shareholders is positively correlated with the profitability of the company, while state shareholders have similarities. This is consistent with the company's profitability, which is consistent with the idea that legal shareholders have a better influence on state shareholders in supervising the board of directors. This is the case of listed companies in the Chinese market. And this essay is based on the research of $\mathrm{Xu}$ and Wang (1997), verifying the hypothesis that the organization's equity has a more positive effect on the state's capital on the business results of the enterprises-listed company in Vietnam.

According to Vo and Ho (2017), institutional investors are expected to play an important role in the stock market, especially in emerging markets. This paper examines the role of institutional investors in the Vietnamese stock market in terms of stock liquidity. This implies the possibility that institutional investors are long-term investors, they do not trade short-term stocks so they do not create liquidity for the market. Another reason is that institutional investors may buy a large number of shares and hold, so the number of remaining stocks traded in the market will decrease, resulting in a decrease in stock liquidity. Nonetheless, institutional investors are expected to play a significant role in the businesses they invest in through good oversight and improved business performance.

H3: The equity of the organization/institution has a positive influence on corporate performance/ business performancel operating results

Personal/individual shareholders: Personal/individual shareholders are very passive in monitoring and managing the operations of the company, except for individual shareholders who are founding shareholders or special shareholders in the company. However, this study is only interested in individual shareholders in general, regardless of special shareholders. With studies in many countries, personal shareholders did not affect the business results of the company, so in the case of Vietnam? This has added an assumption for this study:

H4: Personal-individual equity does not affect corporate performancel business performanceloperating results

\subsection{Xu and Wang's research (1997)}

$\mathrm{Xu}$ and Wang's research (1997) is the foundation for this essay. In their research, the author makes two hypotheses that have been verified and analyzed in many countries introduced in the market. Chinese school. Because of the reliability of this regression model, this paper also applies these two hypotheses in the case of Vietnam, namely companies listed on the HOSE.

\subsection{Pivovarsky's research (2003)}

This research-based on the relationship between ownership concentration and business results of 376 Ukrainian joint-stock companies. The research method is to run cross-section linear regression for the following model: 


$$
y_{i}=\mu+\alpha R_{i}+\gamma X_{i}+\varepsilon_{i}
$$

In which: ${ }^{y_{i}}$ measure the performance of the $\mathrm{i}$ th ordinary enterprise (with three main measures: output factors, material costs per unit of revenue, labor productivity. The reason for choosing these three units as a measure of Ukrainian enterprises is in the process of changing the type of operation, so the profit index as well as the value on the stock market do not reflect the situation of the companies).

$R_{i}$ : a measure of the concentration of ownership, using two quantities of A10 (10 shareholders with the largest proportion/percentage) and HERF (the sum of squares of the 10 largest ownership ratios).

$X_{i}:$ dummy variable represents the industry group.

$\varepsilon_{i}$ : random error.

$\mu, \alpha, \gamma$ : coefficients in the equation.

In it, the most important factor that the model is studying is $t$.

Result: ownership focus has a positive effect on the performance of companies in Ukraine. Moreover, the concentration of ownership of foreign banks or companies has a better effect on business operations than companies owned by domestic shareholders (report the organization's mission and objectives - annual report).

\subsection{Pedersen and Thomsen's research (2000)}

The topic verifies the influence of equity structure on the economic performance of 435 largest European companies. Control by country, industry group, and capital structure, the results show that there is a good relationship of ownership focus on market-to-book value of equity and profitability (asset returns) but to a certain degree of ownership concentration the result no longer shows a good relationship but will be the opposite. Moreover, the author pointed out that depending on the type of major shareholder (family, bank, institutional investor, government, and other companies) has an important influence on strategy and achievement. company. For example, compared to other types of shareholder ownership, the ownership of financial investors is linked to higher stock values and profits but lower profit growth. The influence of ownership concentration is also verified to depend on the type of shareholder ownership.

\subsection{Research model}

The research model of the paper is based on the research model of $\mathrm{Xu}$ and Wang (1997) and has additional hypotheses and concepts (Figure 1). In the model, four hypotheses are stated as follows: results

H1: Concentration of ownership has a positive effect on business performanceloperating

H2: State equity hurts business performance/operating results

H3: The equity of the organization/ institution has a positive influence on the business performanceloperating results

H4: Personal/ Individual equity does not affect business performance/ operating resulta 
According to the research methodology of Xu and Wang (1997) on the topic of structure of equity, corporate governance, and business performance of the company. Applicable to the Chinese stock market, there are two models:

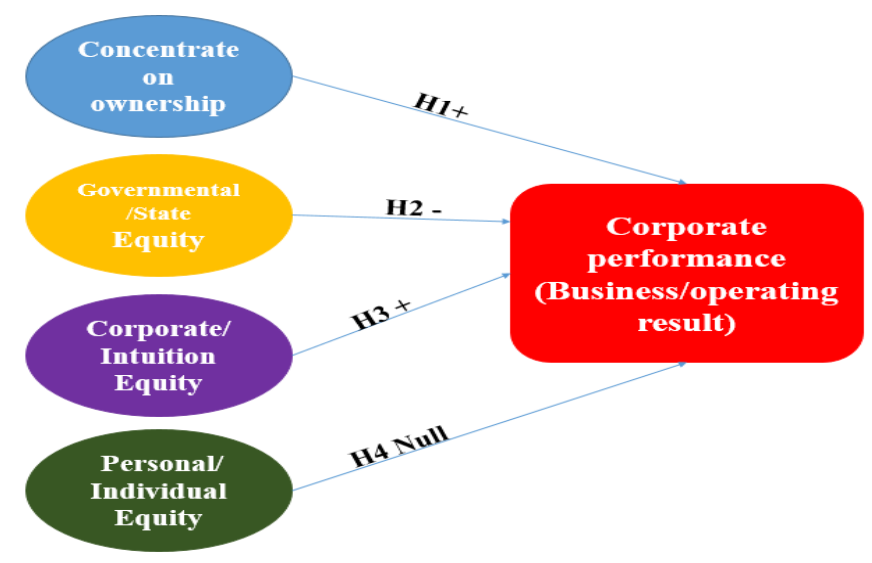

Figure 1. Research model

The first hypothesis (1): $\mathrm{P}$ represents the dependent variables on the business results of the company; $\mathrm{P}$ is expressed by ROA, ROE, and $\mathrm{P} / \mathrm{B}$. CR is the ratio representing the degree of ownership concentration, CR is expressed by A12 and HERF. A12 is the ownership ratio of the two largest shareholders in the company and HERF is the sum of the two squares of the ownership ratio of A12. In the previous study of Xu and Wang (1997), the CR variable was measured by A10 and HERF. However, because the information disclosure of listed companies in Vietnam only stated that the major shareholders have more than 5\% ownership, the information to get 10 biggest shareholders is not enough. There was a research topic focusing on ownership on the HNX, the author used A5, but the regression results did not indicate the effect. The research will not make sense for A1 because then the HERF variable will not work. Therefore, the author decided to research with two the largest shareholder to facilitate information retrieval as well as the basis for Similar research later with A3, A4 ... The HERF variable is also used to measure ownership concentration such as A12 but HERF places more emphasis on large ownership ratios of each ownership rate. For example, company A has the two largest shareholders owning 40\%, 7\%, and company B respectively, and 27\%, 20\%. These two companies have the same A12 ratio, but company A has HERF higher than company B.

First, the paper will run a regression model that verifies the relationship between levels concentration of ownership and business results of the listed company. If verification does not result in linear regression results, it means that there is a degree of concentration of ownership and conclusion Business results of businesses have no relationship with each other. Assume H0: in the tests of $\mathrm{P}$, the coefficient of $\mathrm{CR}$ is 0 The $\mathrm{H} 0$ hypothesis means that the business situation of the company is not affected by ownership concentration. CR will be verified in turn with each variable P. Regression model:

$$
P=\sum_{i=1}^{9} \Phi_{1} F+\Phi_{2} S A L E+\Phi_{3} D A R+\Phi_{4} G R O W+\alpha_{i} D U M_{i}+e
$$

In which:

P: Shows the business situation of the company (through indicators) MBR, ROA, ROE) CR (ownership concentration ratios): the concentration of ownership of group A12 and HERFsquared the rate of ownership of group A12. SALE: revenue (billion VND) DAR: debt/ asset 
ratio, total debt ratio (including debt and bonds issued) on total assets GROW: revenue growth rate over the years DUM: dummy variable showing industry group (companies on HOSE are allocated into 10 industry groups) e: true error, the difference between the actual value and the predicted value. Significance levels for all controls were measured at three levels of $1 \%, 5 \%$, and $10 \%$. Based on the author's observation, the author considers that there is a relationship between $\mathrm{CR}$ and $\mathrm{P}$. That means the $\mathrm{H} 0$ hypothesis is rejected.

The second hypothesis (2): This section will describe deeper to discover the relationship between the owned components business results of the listed company. F represents ownership components. Include $\bullet$ FST - The fraction of equity owned by state $\bullet$ FLP - The fraction of equity owned by the legal person (owned by organizations, domestic company) - FI - The owned by Individuals. In Xu and Wang's study (1997), this ratio is "tradable." A-share". However, to adjust to the Vietnamese environment, the third ownership component will be changed to FI. Hypothesis H0: in the tests of $\mathrm{P}$, the coefficient of $\mathrm{F}$ is 0 . Similar to the above, the H0 assumption means that the business situation of the company is not affected by ownership components. Regression model: In it: variables are similar to the first model. When running the regression model, $\mathrm{P}$ is replaced by $\mathrm{P} / \mathrm{B}, \mathrm{ROA}$, and $\mathrm{ROE}$, respectively, and $\mathrm{F}$ is replaced with FST, FLP, and FI in turn to find the relationship between Turn this together. For example, one of the formulas to be tested is:

$$
\begin{array}{r}
P=\sum_{i=1}^{9} \Phi_{1} C R+\Phi_{2} S A L E+\Phi_{3} D A R+\Phi_{4} G R O W+\alpha_{i} D U M_{i}+e \\
R O A=\sum_{i=1}^{9} \Phi_{1} F S T+\Phi_{2} S A L E+\Phi_{3} D A R+\Phi_{4} G R O W+\alpha_{i} D U M_{i}+e
\end{array}
$$

The above formula is to check the state ownership effect on business performance/ operating results measure by $\mathrm{ROA}$.

$$
P=\sum_{i=1}^{9} \Phi_{1} F+\Phi_{2} S A L E+\Phi_{3} D A R+\Phi_{4} G R O W+\alpha_{i} D U M_{i}+e
$$

\subsection{Research methodology}

This paper analyzes the structure of equity affecting the performance business dynamics of enterprises-companies, comparing business performance among listed companies with similar equity structure in equity structure at different levels of concentration as well as ownership components. In terms of ownership concentration, each company with two shareholders has the highest percentage of equity, called A12. In the paper of Xu and Wang (1997), the focus on owning A10 is the ten largest shareholders, but due to the disclosure of information by the public. Listed companies in Vietnam, the list of major shareholders only raises the number of shareholders owning more than 5\%. Because businesses can not have ten major shareholders owning $5 \%$ or more, this study does not take the A10 list but only two largest shareholders with more than 5\% ownership as representatives, call off is A12. Partly because the information provided by businesses is only capable of obtaining for A12. On the other hand, the less the number of shareholders holding more than $5 \%$ of the equity in enterprises, the lower the concentration, and the more shareholders holding 5\%, the more dispersed. In this study, each listed company only takes the percentage ownership of the two largest shareholders and the square of those two ratios (HERF-Herfindahl index) acts as the main independent variable to run the regression model. 
According to some ways of grouping securities companies, how to group of the Ho Chi Minh Stock Exchange is arguably the most reasonable (Global Industry Standard - GICS®) developed by and is the exclusive property of MSCI Inc. and Standard \& Poor's. MSCI and S\&P rights and have been granted use rights for HOSE.). There are ten major industry groups, which are: (weighted order of number of companies declining trend - decreasing):

1. Industrials, 2. Materials, 3. Financial is replaced by real estate, 4. Consumer discretionary, 5. Consumer staples, 6. Utility services, 7. Health care, 8. Energy, 9. Information technology, 10. Telecommunication services.

Another special case, since excluding financial companies from the sample, but in the financial sector with a small real estate industry, the financial sector is replaced by the real estate industry. When running the regression model, each independent variable and the dependent variable are included in the model. The purpose of running this model is to find out the relationship between equity structure and business results. The sample includes that companies listed on the HOSE, excluding those enterprises, are financial institutions such as banks, investment funds, and certification companies' contract, the insurance company. All are divided into 10 main industry groups. The data on equity structure is collected in annual reports and prospectus tables of enterprises through the three years 2015 - 2017. Variables showing business results of enterprises are collected through the financial statements and annual reports.

\section{Research result and discussion}

\subsection{Descriptive statistics from listed companies}

Collect and list all companies listed on HOSE before and still active in the period 20152017 to form a complete list of companies with 2015 being 283 companies, 2016296 companies, 2017322 companies. After collecting the number of companies taken as a model, the financial sector companies were excluded. In addition, there are a few companies that are removed from the sample analyzed due to some special cases. For example: In 2015, 6 specific companies ATA, GTT because of negative equity (-300.87, -174.68), VLF equity is too small (1.45) can affect data sets and 3 more companies KSS, KTB, PTK because the stock price is too small 1 and not enough data, the ROA and ROE indicators are needed in the year. Similarly in 2016, type 4 ATA, MDG, BHS, ICF companies because of negative equity and not enough DAR index data published in the year. And accordingly in 2017, type 3 companies CSM, DCT, CMG for the same reason. (also note that the DAR, ROA, ROE can be calculated according to the formula from the financial statement but the data is missing for calculation or does not guarantee the conditions for reliability consistency and The value of the data set when analyzing should be removed without analysis.

There are 277 companies in the last complete data set in 2015, 2016 with 292 companies, 2017 with 319 companies. (must be added here in 2017, although the period is until December 31, 2017, however, there are some newly listed companies at the end of the year, the authors have taken stock prices at the end of the year before the beginning of the period to 18/1/2018. As VPG still ensures the fiscal year in time, this is a point to say if the reader is concerned about the time and data is still true to the stock market and the operations of companies in the past year 2018 and currently. The reason why the author did not take until the end of 12.2018 or the present because some companie's financial year has not completed the final report). The average ownership rate of the two largest shareholders in companies over the past three years has been quite high, and not much changed. On average, only two shareholders account for $40 \%$ of the total equity of the business. This shows the high level of ownership concentration of businesses, 
as well as the structure of equity of businesses in Asia, are generally said to be highly focused. Specifically, the average percentage of ownership of two major shareholders in 2015, 2016, and 2017 is $46.47 \%, 46.55 \%$, and $46.22 \%$, respectively.

As can be seen the trend, the number of companies with state ownership and organization accounting for the majority (more than 50\%) in enterprises is declining, while the number of companies with individual ownership rate is higher and higher in specific 3 years 2015, 164 companies / 273 companies, 2016 companies 165 companies / 287 companies and 2017171 companies / 316 companies. This proves that the key management role of the state in companies decreases significantly because the state is conducting equitization, contributing to attracting capital from other types of shareholders. Particularly, individuals are more and more interested in investing in capital contribution to enterprises, so the capital of shareholders in three years has increased. The situation of business performance of enterprises on HOSE floor over the years.

\section{Table 1}

Business performance indicators of listed companies on HOSE on three years 2006-2008

\begin{tabular}{|c|c|c|c|}
\hline & ROA & ROE & P/B \\
\hline 2006 & $10.23 \%$ & $19.62 \%$ & 3.94 \\
\hline 2007 & $9.66 \%$ & $18.00 \%$ & 4.08 \\
\hline 2008 & $9.21 \%$ & $16.82 \%$ & 1.18 \\
\hline
\end{tabular}

Source: Data analysis result of the research

ROA and ROE have been decreasing steadily over the past three years, while the P/B ratio has plummeted in 2008 due to a sharp drop in stock market prices. Original due to the world economic crisis that directly affected the situation of Vietnam's economy, and most heavily affected is the stock market.

\section{Business performance- operating results of listed company on HOSE floor over the years}

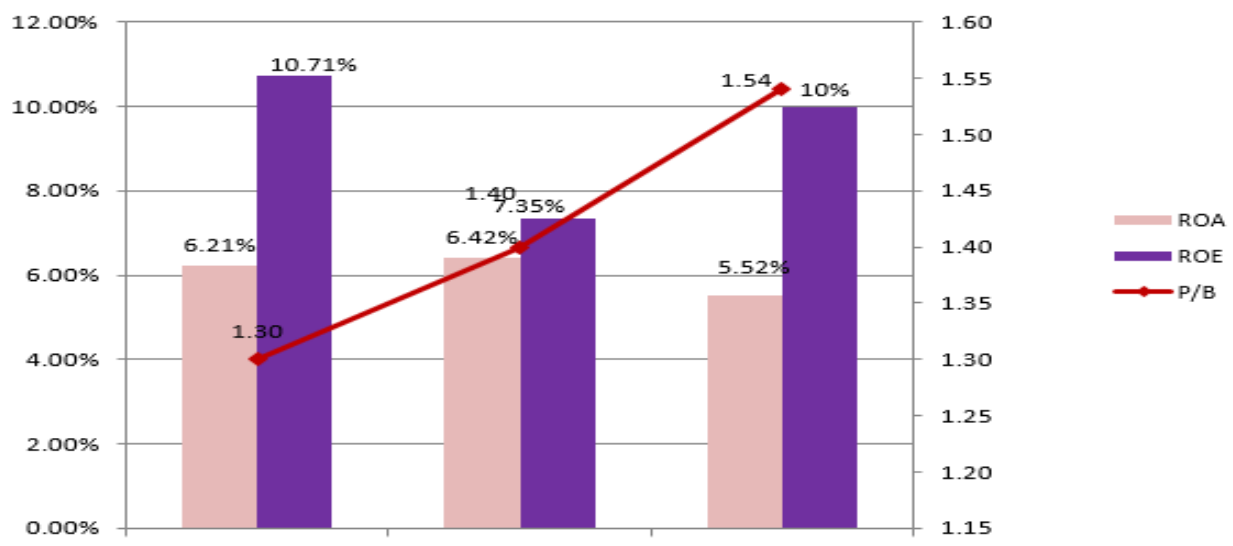

Figure 2. Diagram showing the business performance indicators of listed companies on HOSE in three years 2015-2017

ROA and ROE index fluctuated in three years, while the P/B index increased due to the increase in market share prices and several new entrants to good growth. The cause of the Vietnam stock market in 2016 ROA and ROE decreased, witnessing unexpected shocks from outside with strong impacts like never. That is the fact that few investors think about the possibility of happening, such as the Chinese stock market event interrupted trading on April 1, 
2016, the UK event left EU (Brexit) on June 24, US presidential election results on November 9, 2016. Most of these events have a strong impact on Vietnam's stock market and lead to sell-off activities, even if only from outside fluctuations. On June 24, 2016, VN-Index sometimes fell $5.47 \%$, on November 9, the deepest decline was $3 \%$. However, because the market is still good, it recovered immediately after that.

\subsection{Analyzing the correlation between variables}

Measure the correlation relationship between two quantitative variables for each pair of variables in the two regression models, check whether the variables are correlated with each other before running a regression. Variables will be tested for correlation for each year.

\subsubsection{The year 2006 - 2015}

2006: Based on the table of statistical results describing variables in 2006, we can see between the two ROA and ROE variables, ROA variables are more concentrated than ROE variables due to the smaller standard deviation. The $\mathrm{P} / \mathrm{B}$ variable also has a large dispersion because the prices of stocks differ greatly. Out SALE is the variable with the largest difference due to the business characteristics of the companies the revenue varies widely. The main independent variables such as A2, HERF, FST, FLP, FI have a smaller number of observations the remaining is only analyzed based on the number of companies collected. Variables that only possess FST, FLP, and FI have similar standard deviation but the average of variables the smallest FST and the largest FI. With the minimum result of the component elements owned, variables FST and FLP have min values of 0 , FI variables have min greater than the value of 0 , that is it means that the company does not have state ownership and that the company does not own the group. But every company has individual ownership.

2015: Analyzing the correlation between variables to see the relationship between the variables in the equation. According to the annexed table below, only the business results variables ROA, ROE, P/B (which are dependent variables $\mathrm{P}$ in the hypothetical regression equation) are correlated with the ownership component variables are FST variables, FLP, FI (are independent variables) and control variables SALE, DAR, GROW (are independent variables). There is no correlation between the main independent variables and the control variables on the right side of the regression model, so the linear regression model does not violate the initial set hypothesis of the regression model. linear. In particular, the variable FI is correlated with the variable ROA and ROE in the negative sense of the inverse linear correlation, the FST and FLP variables are correlated with the $\mathrm{P} / \mathrm{B}$ variable. Thus, there is a relationship between state ownership and organization with business results.

\subsubsection{The year 2007 - 2016}

2007: Compared to 2006, the variables with standard deviation did not change much, only the index SALE has a larger mean than 2006 but a smaller standard deviation shows results The turnover of businesses in 2007 was much higher than in 2006, as well as the higher GROW average, but the ROA average and smaller ROE than in 2006 due to the assets and invested capital of the enterprises higher. The average of $\mathrm{P} / \mathrm{B}$ is also higher, reflecting the true reality. In 2007, stock prices increased sharply due to Vietnam's stock market in 2007 is very developed. The main independent variables in 2007 compared to 2006 have not changed much. Just there was an FLP variable in 2007 with a min value greater than zero, meaning that in 2007 most of the time The companies on the HOSE have the ownership of the organization, and all listed companies Lists are owned by individuals, but some businesses do not own the state. 
2016: The results of 2016 show that there are many correlations between the dependent variables and the main independent variables and control variables but there is no correlation between the main independent variables and the control variables of the right side. linear regression, separate correlation relationship of two variables SALE and DAT with a small coefficient of Pearson 0.148 sig 0.12 is statistically significant at a 5\% significance level. In 2016, the business results of the business correlated with the ownership and ownership components of the state and organization.

\subsubsection{The year 2008 - 2017}

2008: 2008 is the year of economic crisis, so the average value of ROA and ROE variables Smaller than the previous two years, the standard deviation is greater indicating the degree of dispersion of wide variables, much difference because businesses have no business results evenly. The P/B index has changed the most, the average value has sharply decreased compared to 2006 and 2007, the standard deviation is also smaller because all stock prices are equal plummeted in 2008. The main independent variables A2, HERF, FST, FLP, and FI have not changed many previous years. State ownership is the highest in a nearly equal business $70 \%$ and enterprises without state ownership. Property of the organization - the highest proportion of an enterprise is $90 \%$ and some enterprises do not own the organization. As for the type of individual ownership, all businesses have individuals who own and have businesses $100 \%$ owned by individuals without other types of ownership.

2017: According to the results of the above table, there is only a correlation between the dependent variables and the main independent variables and control variables, there is no correlation between the main independent variables and the control variables on the right side of the linear regression equation. 2017 shows that there is a close correlation between 2016 and only the highest change value is the P/B related index because the stock value changes due to the "black swan" effect on the Vietnam stock market in general and HOSE of course expressed as mentioned in the above analysis.

\subsection{Regression model}

\subsubsection{Testing hypothesis regression model 1}

Hypothesis H0: in the tests of P, the coefficient of CR is $0 \mathrm{CR}$ is replaced with A12 and HERF. The tested model with each dependent variable ROA, ROE, and P/B shows the end business results. Note: There is an important change in this model when running regression, the author forced must remove the DUMMY variable from the model for two main reasons: - First: The research sample is companies listed on HOSE with quantity limited company. - Second: Information collected from companies is incomplete, so when regression runs, the author must eliminate some companies that do not have enough information. From the above two things, the study sample is reduced more so the grouping is equal using DUMMY - dummy variable will give unreliable results because the sample is removed. Although the DUMMY variable is the most commonly used in studies similar to this topic, it is only suitable for a sample size that has not been removed, while subdivision still ensures a sufficient number of companies for each group to be meaningful when running a regression.

\section{The regression results with ROA variable is the dependent variable.}

CR is replaced with variables A12 and HERF in turn to verify the relationship between business results of enterprises and the level of equity concentration. 2015, 2016 and 2017 results show that ROA and CR (both A12 and HERF variables) there is no linear correlation with each 
other because of the value of Sig. of test t-test is too large, exceeding all three significance levels of $1 \%, 5 \%$, and $10 \%$. Overall, for all three years, the hypothesis test results show that the variable CR does not have a linear relationship with the ROA variable, because the significance level of statistical value is too large. Thus, the hypothesis result of hypothesis $\mathrm{H} 0$ for variable ROA is the dependent variable for three years, which results in not rejecting the hypothesis H0. So, there is no linear relationship between the dependent variable ROA and the independent variable CR, or the concentration of equity does not affect the business results of enterprises/listed companies measured by ROA.

\section{The regression results with ROE variable is the dependent variable.}

In $\mathrm{Xu}$ and Wang's study (1997), when running a linear regression for the dependent variable ROE, the control variable GROW is excluded because GROW is the growth of net profit so ROE and GROW have a linear relationship with each other. However, in this analysis, GROW is the growth of revenue, so GROW and ROE have no linear relationship with each other. Therefore, GROW variable is not excluded. The regression model when running ROE variable is the dependent variable. From the statistical results that can be concluded in this study, the CR variable does not affect the ROE variable.

\section{The regression results with $\mathrm{P} / \mathrm{B}$ variable is the dependent variable.}

The model when running with the variable $\mathrm{P} / \mathrm{B}$ is the dependent variable: The results showed that in three years, the $\mathrm{CR}$ variable did not affect the $\mathrm{P} / \mathrm{B}$ variable. It means that ownership concentration has no linear meaning with the business results of the enterprise shown by the P/B index. General perception: The results of the hypothesis test for all three years 2015 to 2017 have one thing in common, which is that the owner does not affect linearly on business results. According to the author, it is possible for the following reasons: 2015, 2016, 2017 are 3 years that investors rush to invest in the market largely following the crowd psychology, without clear analytical knowledge. The investment purpose of investors is speculation in the short term, so the ownership rate is not much related to corporate governance and therefore, does not affect the business results of the enterprise. In addition, many newly listed companies and listing cancellations also took place. For this reason, the author can only explain why the results are not as expected. But with the implemented method, the hypothesis test results show hypothesis $\mathrm{H} 1$ is rejected because most of them have no linear correlation between ownership concentration and the company's business results.

Compare in previous 2006-2008 the trend:

The hypothesis test results for all three years from 2006 to 2008 have one thing in common, that is in 2006 and 2008 variable owners do not have a linear effect on business results, but 2007 is linear. According to the author's judgment, maybe for the following reasons: Firstly, 2006 is the beginning year of the Vietnam stock market boom Nam, the investors rushing to invest in the market largely followed the crowd, no have clear analytical knowledge. The investment purpose of investors is to speculate to make a profit in the short term, so the ownership rate is not much related. corporate governance and, therefore, does not affect business performance business. Secondly, in 2006, the companies announced incomplete information, so the collection of information needed for the thesis is limited, reducing the number of companies in the sample, leading to unreliable results. Thirdly, 2007 is the year the securities laws came into effect, the information More transparent disclosure, improved investment experience of investors. Moreover, there is the intervention of state management agencies, so the ownership rate of the capital in the companies is adjusted. Therefore, the results Regression run of all three indicators ROA, ROE, and $\mathrm{P} / \mathrm{B}$ showed a positive linear to the percentage of ownership. 
Fourthly, 2008 was the year the world economy in crisis, Vietnam economy nor exception. This has greatly affected the market Vietnam stock market. Therefore, the linear regression results for all three threads numbers did not reach as expected. For the above reasons, the author only explains why the results are not as expected. But with the method used, the hypothesis test results show the hypothesis $\mathrm{H} 1$ is rejected because there is almost no linear correlation between ownership ratio and Business results of the company.

\subsubsection{Testing hypothesis regression model 2}

Hypothesis $\mathrm{H} 0$ : in the tests of $\mathrm{P}$, the coefficient of $\mathrm{F}$ is $0 \mathrm{~F}$ is replaced with FST, FLP, and FI are components owned by the state, organization, and individuals. Because the supply of information of businesses is not enough, the model of different FST, FLP, and FI variables. For the FST variable (owned by the state), businesses have more complete supply data observation, so the sample is observed more than FLP and FI variables. Similar to the reason for the first hypothesis model, there is a change in this second hypothetical regression model, the model eliminates the DUMMY variable for the reasons mentioned above.

\section{The regression result with the variable FST is an independent variable.}

Regression model of the FST variable. In which, $\mathrm{P}$ is replaced by ROA, ROE and P/B. Considering the results with the variable ROA, ROE, P/B is the main dependent variable Perform regression run for FST variable is the main independent variable and variable ROA, $\mathrm{ROE}, \mathrm{P} / \mathrm{B}$ are dependent variables respectively, the results show that ROA, ROE, P/B have no linear regression relationship with FST in all three years from 2015 to 2017. This can be explained by the structure of enterprise equitization, so the state factor has little impact on ROA, showing a profit on total assets, ROE only Return on equity, $\mathrm{P} / \mathrm{B}$ ratio between stock price and a book value of that stock at a specific time. Hypothesis $\mathrm{H} 2$ is rejected and the hypothesis is the null hypothesis (not linear).

\section{The regression result with the variable FLP is an independent variable.}

Considering the results with the variable ROA, ROE, P/B is the main dependent variable Perform regression run for variable FLP is the main independent variable and variable ROA, ROE, P/B are dependent variables. Respectively, the results show that ROA, ROE have no linear regression relations with FLP in all three years from 2015 to 2017. FLP alone has a positive and significant effect since the significance of the statistical value reached 0.007 is acceptable at the significance level of $1 \%$ and $5 \%$ in 2017 . Thus, according to the verified results, the ownership ratio of the organization has a positive and positive effect on the business results of the listed company through P/B in 2017. Likewise, Hypothesis H3 has been accepted, investments from organizations play an alternative role in state equitization.

\section{The regression result with the variable $\mathrm{FI}$ is an independent variable.}

Following the results with the variable ROA, ROE, P/B is the main dependent variable. Perform regression run for FLI variable is the main independent variable and the variable ROA, ROE, P/B are dependent variables. Respectively, the results show that ROA, ROE have no linear regression relationship with FLI in all three years from 2015 to 2017. Particularly, FLI has a negative and significant effect because the significance level of statistical value reached 0.008 , 0.003 , respectively, accepted at the significance level of $1 \%$ and $5 \%$ in 2 years 2015 and 2017 . The bigger the FLI, the smaller the P/B and reversed the value trend as on the contrary. Thus, the hypothesis H4 Null has no linear regression correlation is rejected.

Compare in previous 2006-2008 the trend:

In 2006, the state ownership rate had a positive influence on the performance the 
company's business performance is through the ROA and ROE with the standard ratios are 0.189 and 0.256 , respectively. Thus, the state ownership rate affects the ROE more strongly than the ROA. 2007 In 2007, the proportion of state ownership had a completely positive effect on the results business performance on all three indicators ROA, ROE and P/B. In particular, the ROE is most affected by the coefficient of 0.345 , followed by the ROA with the coefficient of 0.328 and finally the $\mathrm{P} / \mathrm{B}$ ratio with the coefficient of 0.3 . In 2008 , the state ownership ratio was positively correlated to all three indicators ROA, ROE, and $\mathrm{P} / \mathrm{B}$ numbers. In particular, the state ratio affects the ROA and $\mathrm{P} / \mathrm{B}$ ratios with the same standard coefficient of 0.187 , for ROE with a coefficient of 0.16 . Thus, ROA and $\mathrm{P} / \mathrm{B}$ are positively affected by the state ownership ratio with an equal level and higher than ROE. In summary, the regression results show that the ownership ratio of the state is linearly positive to the company's business results, which negates the hypothesis that $\mathrm{H} 2$ is state ownership with a negative influence. on the business results of the listed companies. This result can be explained by two possibilities: The first possibility is due to the quality of state management in businesses. The second possibility is due to the state's economic support policies. The support policies that are preferential policies, subsidies, create many favorable for the State-owned companies such as tax exemptions, capital supplies, loan interest rate support, ... so most of these companies have better business results than other Enterprises have a lower level of state ownership. However, according to many reviews and reports of the World Bank (2006), the perception that the quality of state management in Vietnam is very low. Therefore, the second possibility is considered the most reasonable.

\section{Conclusion and management findings}

After collecting full data of companies listed on HOSE according to the form. For three years of research, the regression process has yielded answers given by the hypotheses in the topic and fulfilled the original goal. The research results show that the structure of equity has an impact on the business performance of businesses and is only affected by ownership components. Specifically, the results in two linear regression models are as follows:

- The first model: the impact of ownership concentration on the business performance of the business. The results show that for Vietnam, ownership concentration almost does not affect the business performance of listed companies during the period years from 2015 to 2017 (new data recently and in the period 10 years with comparison 2006-2008 also same result and trend). Particularly, in 2007, some results were showing that ownership concentration had influenced companies, but the results showed very little and unevenly in regression runs, so it could be considered as no correlation. However, there is no relationship between ownership concentration and the business results of enterprises. The overview date in 10 years is consistent. This result is different from previous studies such as research. Xu and Wang (1997), Pivovarsky (2003), Pedersen and Thomsen (2000). All three studies result in a concentration of ownership that positively affects the business results of companies.

- The second model: the impact of ownership components on the business results of the listed companies. The state-owned component does not have a positive effect on the business results of enterprises in the regression results showed in all three years 2015-2017 in comparison with 2006-2008. In this model, the state ownership component has an image that positively impact the business results of the enterprise. The regression results show that in the three years, the higher the state owns, the better the business results of enterprises, namely through two indicators ROA and ROE. This rejected the initial assumption that the higher the proportion of state ownership would be the results of the business are as good as some previous studies in other countries. The reason is that state-owned enterprises are favored by the state with many 
policies and supports in their operation, which is a fact in Vietnam because state-owned enterprises are managed by the state. The section represents Vietnam's economy and government. In contrast to state ownership, organizational ownership has a negative influence on business results of enterprises, regression results are most evident in 2006 and 2007 through the two indicators ROA and ROE. The coefficients are all negative. This has rejected the initial hypothesis that higher state ownership rates have a negative impact on the business results of enterprises as some previous studies in other countries. The reason is that enterprises with stateowned capital are declining in the stock market due to the structure and policy of equitizing enterprises to expand and attract investment from foreign capital.

In contrast to the results of the previous study, as reported by $\mathrm{Xu}$ and Wang (1997). Finally, personal/individual ownership, this ownership component has a negative linear correlation affecting the business results of companies during the period 2015-2017. The data set reflects the true nature of Vietnam's stock market in general and through HOSE, the diversification of products in the market helps enhance the attraction of diverse participation of investors. Private investment increase capital mobilization and develop an investor base. In the stock market, the main products are stocks of listed companies. The legal basis for issuance and listing has been revised in a tighter direction, at the same time regulating the content of information disclosure and corporate governance, improving the openness and transparency of the market and each access to international standards has gradually screened and eliminated businesses with weak capacity, inefficient operation, creating a supply of high-quality stock codes for investors. This is reasonable because in general, the Vietnamese government market is not diversified, mainly focusing on several basic investors, not many professional investors. In the stock market, individual investors currently account for most total securities investment accounts. This is a common feature in newly developed stock markets, similar to regional countries such as Thailand, Philippines... This will make the stock market more volatile because individual investors are easily influenced by different factors (psychology, information, domestic and foreign fluctuations), which will be limited at institutional investors. The number of individual investors, especially individuals with limited knowledge/ experience in securities investment, can also be taken advantage of crowd psychology to implement violations of regulations such as "making prices", interior exchange...All the above is the change, look back the period 2006-2008 all significant levels of statistical value t exceed the acceptable significance level.

\section{References}

Albert, A., \& Owusu, A. R. (2014). The effect of ownership structure and corporate governance on capital structure of ghanaian listed manufacturing companies. International Journal of Academic Research in Accounting, Finance and Management Sciences, 4(1), 109-118. doi:10.6007/IJARAFMS/v4-i1/547

Anderson, R. C., Mansi, S. A., \& Reeb, D. (2003). Founding family ownership and the agency cost of debt. Journal of Financial Economics, 68(2), 263-285. doi:10.2139/ssrn.303864

Cao, T. H. (1998). Thống kê úng dụng trong kinh doanh [Statistics in business applications] (Lecture notes). Khoa Quản lý công nghiệp, Trường Đại học Bách Khoa TP.HCM, Vietnam.

Çitak, L. (2011). The impact of ownership structure on company performance: A panel data analysis on istanbul stock exchange listed (ISE-100) companies. Journal of Financial Markets Research, 9(2), 34-46. 
Demsetz, H., \& Lehn, K. (1985). The structure of corporate ownership: Causes and consequences. Journal of Political Economy, 93(6), 77-115.

Faccio, M., Lang, L. H. P., \& Young, L. (2001). Dividends and expropriation. American Economic Review, 91(1), 54-78 . doi:10.1257/aer.91.1.54

Fama, E. F., \& Jensen, M. C. (1985). Organizational forms and investment decisions. Journal of Financial Economics, 14, 101-119. doi:10.1017/CBO9780511817410.024

Hoang Trong \& Chu, N. M. (2008). Phân tích dĩ liệu nghiên cưu với SPSS [Analyzing research data with SPSS]. Hanoi, Vietnam: Nhà xuất bản Hồng Đức.

Karpoff, J. M., Malatesta, P. H., \& Walkling, R. A. (1996). Corporate governance and shareholder initiatives: Empirical evidence. Journal of Financial Economics, 42(3), 365395. doi:10.1016/0304-405X(96)00883-5

Nguyen, H. D., \& Dau, C. T. (2003). Xác suất và thống kê [Probability and mathematical statistics]. Ho Chi Minh, Vietnam: Nhà xuất bản ĐH Quốc Gia Tp.HCM.

Pedersen, S., \& T. \& Thomsen, S. (2000). Ownership structure and economic performance in the largest European companies. Journal Strategic Management, 21(6), 689-705. doi:10.1002/(SICI)1097-0266(200006)21:63.0.CO;2-Y

Phung, N. D., \& Mishra, A. V. (2016). Ownership structure and firm performance: Evidence from Vietnamese listed firms. Journal Australian Economics Ppaper, 55(1), 63-98. doi:10.1111/1467-8454.12056

Pivovarsky, A. (2003). Ownership concentration and performance in Ukraine's privatized enterprises. IMF Staff Papers, 50(1), 10-42.

Reeb, D. (2007). Ownership structure and corporate decision-making. Journal of Economics \& Business, 59(5), 355-357. doi:10.1016/j.jeconbus.2007.04.001

Rui, O. M., Firth, M., \& Fung, P. M. Y. (2002). Simultaneous relationships among ownership, corporate governance, and financial performance. Retrieved July 11, 2019, from https://papers.ssrn.com/sol3/papers.cfm?abstract_id=337860

Thanh, P. N. T. (2009). Ownership structure, corporate governance and corporate performance: The case of Vietnam (Unpublished bachelor's thesis). Đại học Quốc tế, Vietnam.

Vo, V. X., \& Ho, T. V. (2017). Vai trò của nhà đầu tư tổ chức đối với thị trường chứng khoán Việt Nam [The role of institutional investors in Vietnam's stock market]. Tạp chí Kinh tế Đối ngoại, 97(97), 1-12.

World Bank (2006). Báo cáo về tình hình tuân thủ chuẩn mục và nguyên tắc (ROSC). Đánh giá Tình hình quản trị công ty của Việt Nam Tháng 6/2006 [Report on standards and principles compliance (ROSC). Assessment of corporate governance in Vietnam 6/2006]. Retrieved August 20, 2019, from http://thuvien.mku.edu.vn/doc/bao-cao-ve-tinh-hinh-tuanthu-chuan-muc-va-nguyen-tac-rosc-danh-gia-tinh-hinh-quan-tri-cong-ty-c-43952.html

Xu, X., \& Wang, Y. (1997). Ownership structure, corporate governance, and corporate performance: The case of chinese stock companies. Retrieved August 15, 2019, from https://papers.ssrn.com/sol3/papers.cfm?abstract_id=45303 